\title{
Food Risk Management and Sustainable Development
}

\author{
Fedali Yamina, Bourmada Noureddine, Djebabra Mebarek \\ LRPI Laboratory, Institute of Health and Industrial Safety, University of Batna, Batna, Algeria \\ Email: fedaliyamina@yahoo.fr
}

Received 3 February 2014; revised 2 March 2014; accepted 1 April 2014

Copyright (C) 2014 by authors and Scientific Research Publishing Inc.

This work is licensed under the Creative Commons Attribution International License (CC BY). http://creativecommons.org/licenses/by/4.0/

(c) (i) Open Access

\section{Abstract}

For several years, the food industry sets up its own systems of controls and risk management to insure the healthiness of the products which it puts in market and as the last years were marked by the deep change of behavioural companies towards the natural, resource management, and the environment-friendlier adaptation of policies. The majority of these food-processing companies favored the introduction of methodologies of risk management in a concept of sustainable development which aims at expressing the access to a quality food supply, while contributing to the social and economic long-term development and also to protect the environment for the future generations. The integration of the idea of durability in the food processing industry by the implementation of a common system of management of the risks according to the food codex and by means of the method HACCP (Hazard Analysis and Critical Control points) aims at ensuring a better quality of life through the implementation of actions centered on health, by the control of the food chains. Our contribution, which becomes integrated into context, consists in bringing to light the factor health as a pillar into interface with the other themes to know the social, the economy and the environment.

\section{Keywords}

Sustainable Development, HACCP, Food Industry, Risk Management

\section{Introduction}

The food industry sector has become aware of the specific risks generated by this type of installation and its impact on the population health, which has raised a number of questions related to the management system which can provide information reliable on the safety and quality of the products coming to the consumers. All food can be contaminated in different ways and at levels that can cause disease more or less severe (such as, for example di- 
gestive and nervous disorders, fever, vomiting, abortions, injuries, choking...), and can even cause death [1]. These risks of contamination exist in every company that manufactures sells or transports food. They can occur at every link in the chain representing the succession of the stages through which products move from their entry to the exit of the company [2]. The management of the food security consists to acting as a barrier for the defective components and the imperfect finished goods. A reception control for the purchased materials, inspections during the manufacture and verification of the finished products constitute the classical phase of the management of the safety and quality of food [3]. In the food sector the Codex Alimentarius Commission creates the FAO, and the WHO which was founded in 1962. There are also other regulatory references such as ISO 9000, 9001, 9004 and ISO 22000, which all of them have a common objective and that is the control of risks in this kind of sectors [4].

The food security has undergone a considerable development with the implementation of HACCP (Hazard Analysis and Critical Control Point) system, which is a systematic approach which aims to identify, evaluate and control the physical, chemical and biological risks along the whole production process [5], and it has therefore become the tool of control of the food hazards [6], the HACCP constitutes a reference base to the food safety, it provides a systematic method for analyzing the food processes, identifying potential risks and specifying their critical control point (CCP), to avoid the distribution of unsafe food to consumers [7].

Large part of humanity is faced with serious threats because of the food conditions are not in their favor. Confronted with such threats, we have to look for means to permanently ensure food safety and preserve the natural capital which conditions it. Generally, the decisions are difficult to take for various reasons, some of which are political considerations, social values, economic problems and legal issues [8]. But it is still science which is the most important element in decision-making for food risks assessment. It is for these reasons that the management aspect of food risks is considered as essential in the policy of food safety based on rigorous scientific criteria. So, the innovative integration of a sustainable development approach will be made by progressive actions using the results of a management system through the HACCP tool whose opportunities will [9]:

- Allow risk management using control procedures which have been implemented in health, food safety, environment, and working conditions;

- Help elaborate a common and progressive working document which deals with sanitary safety problems while suggesting a coordinated approach.

In this paper we try to overcome by introducing an original methodological approach which demonstrated two research axes:

- The first one was centered on the demonstration of the interest of the HACCP system implementation so as to provide the various companies with an efficient tool which evaluates and masters the dangers threatening food healthiness;

- The second part of the work helped establish an integration framework of this self control system in a policy of sustainable development, which aims at preventing the development of serious pathologies with nutritional constituent so as to ensure the durability of its activities, and which constitutes an innovation tool for the food-processing industry.

During this work, we present the following points and which will be the base of integration of our approach:

- The food industry on the way of durability;

- The Risk management by the HACCP system;

- The importance of the HACCP system for a sustainable development.

\section{The Food Industry on the Way of the Durability}

The World Conference on Environment and Development Rio De Janeiro 1992 granted a wide place to sustainable development and food safety. "Food safety is assured when all the persons have at all moments the physical and economical average to get food stuffs in safe and nourishing quantities to cover their food needs and let them lead an active and healthy life" [10]. So, durability means maintaining a certain degree of welfare for all persons that will not deteriorate through time. Therefore, the concept of sustainable development gives a new input to the food industry in the sense that it helps integrate the specific constraint of sustainable development in rational management [11]: Resources, respect of the environment, and reflection on the use of biotechnologies.

The biological component of the production of food stuffs is directly related to the reflection on the sustainable development of these industries. As an example, we can quote the recent public debates on genetically modified organisms, on diseases caused by food, on the environmental issues related to breeding and fishing, on north-south commercial exchanges, on public policies of resources management and markets support. 
The objectives of food safety in the sustainable development policy are multiple. The most remarkable ones are [12]:

- Support to organizations and communities in the development and to organizations dedicated to education and awareness in order to improve the living conditions of the populations;

- Implementation and management of programs of production, distribution and access to food;

- Development of tools and participative methods in the field of food safety management and environmental protection;

- Food as a constituent of the right to live: consider food safety with development policies, that is, taking into account the interactions with the socio cultural and the process of governance (principle of balance between economic growth, social development and environmental protection).

In this study, we tried to make an investigation on the question relative to the sustainable development and to see sound degrees of integration in certain food-processing industries, and we ended in the following results: Figure 1 and Figure 2.

\section{The Risk Management by the HACCP System}

The term "hazard analysis and critical control point (HACCP)" has been progressively recognized as a cost-effective procedure for ensuring food safety. Today, this methodology is internationally accepted as an effective tool to deal with safety hazards which may arise in the food production process [13]. Since the adoption of the Codex Alimentarius "guidelines for the application of the hazard analysis and critical point (HACCP) systems" and subsequent revision "hazard analysis and critical control point system and guidelines for its application", the use of its seven application has become mandatory prerequisites in the food worldwide production chain [14], in order to prevent the occurrence of food safety hazards to final customers. For reinforcing public health security it has been to urged the implementation of full HACCP in all food businesses [15].

The proposed principles are different from those of the Codex and no mention is made of the need for normal HACCP plans [16].

HACCP identifies risks in the production processes that can lead to unsafe products, and designs measurements to reduce these risks to acceptable levels. HACCP is designed for application in all links of the food chain, HACCP involves seven principles [17]:

- Analyze hazard (biological, chemical or physical);

- Identify critical control points (these are points in a food production at which the potential hazard can be controlled or eliminated);

- Establish preventive measures with critical limits for each control points;

- Establish procedures to monitors the critical control points;

- Establish corrective actions to be taken when monitoring shows that a critical limit has not been met;

- Establish procedures to verify that the system is working properly;

- Establish effective recordkeeping to document the HACCP system.

In the management of food risks, critical control point huge system step has been made with the application of from HACCP implementation helps not only to identify the risks and control them and especially reinforce the self control of the food-processing companies.

In this context, the role of the governments is to encourage the industries and help them adopt this system which helps: to analyze the risks which can occur, to describe critical points and their limits and to supervise and check the efficiency of the HACCP system.

Of course, the HACCP system is specific to each company where each case constitutes a particular study. Consequently, its implementation depends on the company's decision. Furthermore, the HACCP system uses specific assistance tools. For example, for the determination of the CCP, we use the tool "tree of decision" whose elaboration is made thanks to a set of questions related to every risk and to every stage of the process, including the reception and the processing of raw materials.

\section{The Importance of the HACCP System for a Sustainable Development}

The management policy of food safety is an approach to sustainable development which mainly aims at gathering data based on scientific criteria while respecting the essential principles related to food safety. The latter is largely taken into account by the Codex Alimentarius which is composed of food standards and practical codes giving guidelines and recommendations on food security and food security management systems on the model 
For the environmental protection

For a gain on the economic plan

The commitment of the business manager

To limit the risks

Compulsory requirements

Figure 1. Why would you apply the sustainable development in your company?

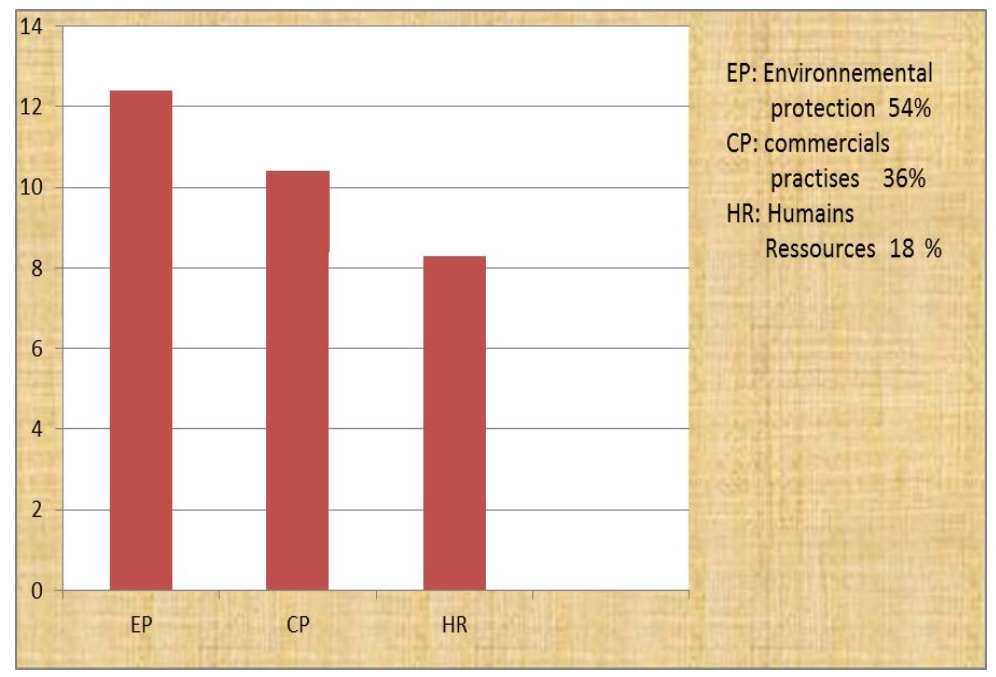

Figures 2. In the following domains would you build up actions connected to the sustainable development?

of the HACCP system which is an instrument intended to assess hazards and to establish systems of control centered on prevention instead of calling upon procedures of a posteriori control of the finished product several works were conducted in this domain to show the importance of the integration of the sustainable development in management practices [18]-[21].

In practice, and for reasons of efficiency, food safety should integrate, in its management, requirements for sustainable development whose objective is to offer a product of quality while respecting the principle of balance between economic growth, social development and environmental protection [22].

Companies must then take steps by adopting plans and measures aiming at the improvement of the environmental profile of their activity (inputs, waste) or of their products (current energy consumption, management of life cycle) as well as the consideration of the social factor [23] interfering directly or indirectly in these activities (see Figure 3).

\section{Stakes in the Integration of the HACCP for a Sustainable Development Policy}

We note, after the application of the step HACCP system, that the most propagated risk is the presence of pathogenic bacteria which can have harmful effects on the consumers. The application of this approach has determined the parameters on which it is necessary to act (CCP) and the control measures, thus guaranteeing the effi- 


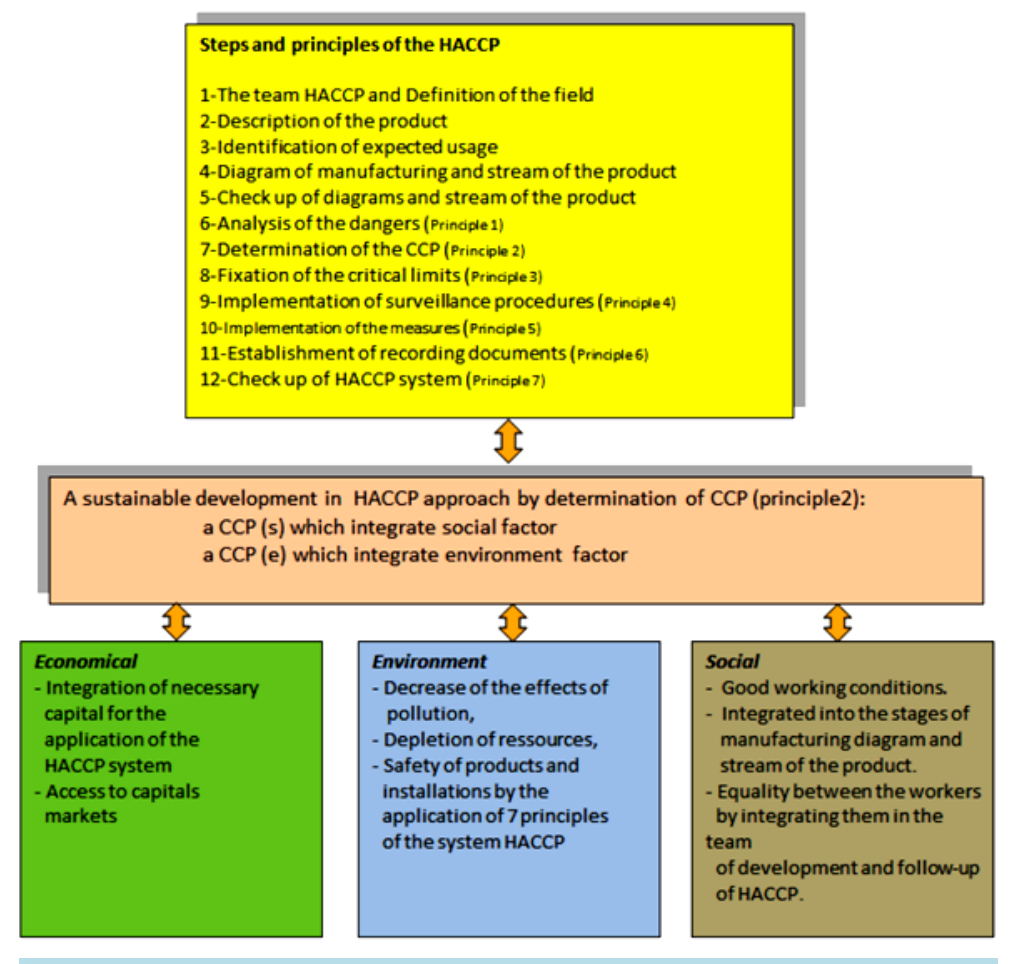

Figure 3. Integration of HACCP system in sustainable development steps.

ciency of preventive measures and reducing the dependence on the inspections of finished products.

The HACCP system can be applied all along the food chain, from the primary producer up to the consumer (on the whole life cycle of products), and it can also improve the sanitary safety of the food. The HACCP system allows, on the other hand, a better use of the energetic and economic resources [24].

So it comes at the forefront for its integration in a sustainable development policy which will be profitable to the industries working in the food processing field because it will help guarantee a long-lasting consumption by the design of appropriate products and services which require less energy and resources and which do not present any danger [25].

During the implementation of the HACCP system, we drew up a plan grouping together the main stakes in the sustainable development which must be considered by these industries (see Figure 4).

The general aims of this figure is to identify the key aspects (social, environment, economical) in the sustainability field in order to set up an integrated method, which will help Companies to develop a policy of integration with regard to their activities. In this context, the objective of this figure consists in bringing to light the health factor as a pillar in this approach of sustainable development while integrating into the interface the other themes, namely the social and the economic factors.

\section{Social}

- Sanitary quality by traceability actions and the results of the HACCP;

- Training of professional staff;

- Communication and information about the obtained results;

- Insure food quality through quality labeling;

- Ameliorate the working conditions using ergonomics and studies about the medium hygiene;

- Be economically responsible of buying for products from convenience stores.

\section{- Environment}

- Decrease water and energy consumption by professional staff;

- Use cleaning equipment's with weak and energy consumption;

- Decrease raw material consumption by the amelioration of food consumption systems and fight against all kinds of waste;

- Limit the costs by the actions of energy and raw material saving. 


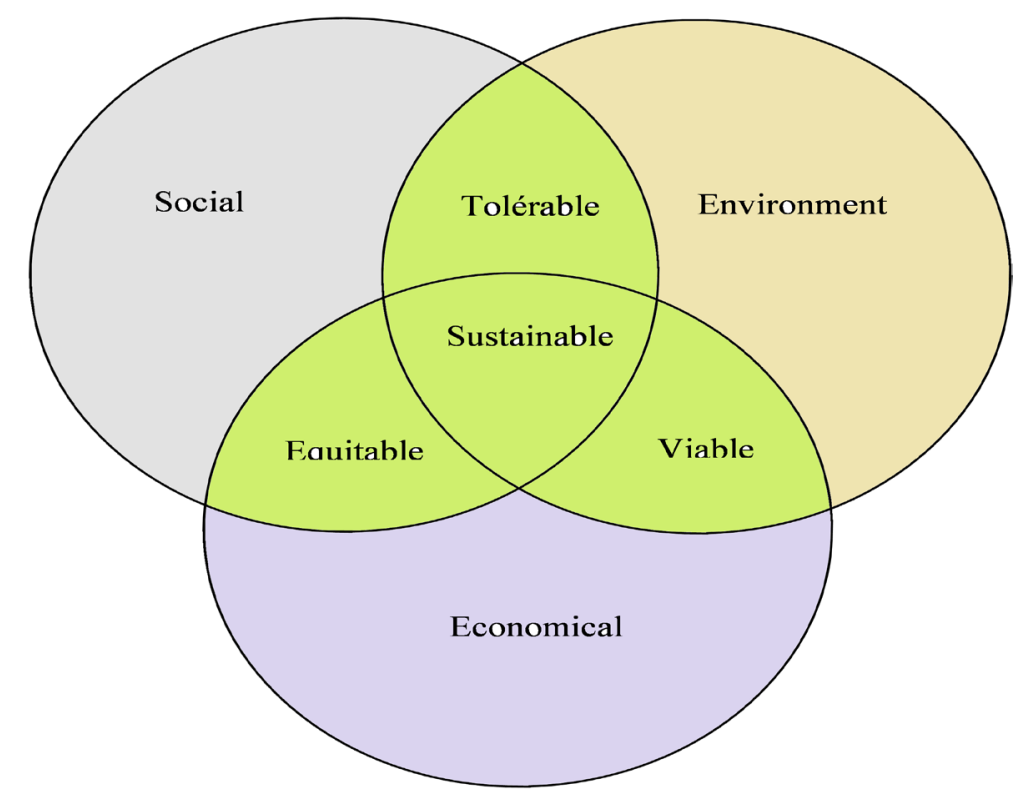

Figure 4. Main stakes of the sustainable development in food industry.

\section{Economical}

- Be economically responsible of buying for products from convenience stores;

- Establish confidence between supplier, customers and consumers.

\section{Conclusions}

Food Safety hazards may be assessed and appear at a stage of food chain "from farm to fork", and it is the objective of the new international standard ISO 22000-2005 "food safety management systems requirements for any organization” in the food chain "ISO.2005".

This new standard dedicated to the food safety management, should supply a precious complement in the approach HACCP. Its presentation is a guide for the identification, and the evaluation and the maitise of the sanitary risks are applicable to all the stages of food chains. His requirements concern at the same time the conditions of production and the quality of products, and his executive is the same of the norms ISO9001 or 14001, what permit a global approach (QSE), ells conferment thus an ethical approach in the activities, the result ( of an awareness of the imperatives of a sustainable development, in the implications important for the environmental and economic, social future of our systems.

As far as food security is concerned, the HACCP approach dispyte all inconveniences. This approach still remains as one of the most applicable, and also it is considered as the most appropriate. The integration of a food company in a sustainable development optic, through this work, we project to associate and combine other main and tools with HACCP particularly ACV product, for a innovative approach to encircle better the problem.

\section{References}

[1] Hahelle, C. (2005) Risques et crises alimentaires. Collection science et techniques agroalimentaires Lavoisier.

[2] Luning, P.A. and Marcellis, W.J. (2006) A Technomanagerial Approach in Food Quality Management Research. Food Science and Technology.

[3] Codex Alimentarius (1993) Guidelines for the Application of the Hazards Analysis Critical Control Points. System ALINORM 93/31.

[4] Codex Alimentarius Commission (1997) Hazard Analysis Critical Control Points (HACCP) System and Guidelines for Its Application. General Requirements (Food Hygiene), 1B, 33-45.

[5] Nellema, S. and Boselia, D. (2003) Cooperation and Competence in Global Food Chain. Perspectives on Food Quality and Safety. Shaker Publishing, Maastricht.

[6] Lunning, P.A., Develienghere, F. and Verhe, R. (2006) Safety in the Agrifood Chain. Wageningen. Academic Publish- 
ers, Wageningen.

[7] Stevenson, K.E. (1990) Implementing HACCP in the food Industry. Food Technology.

[8] Trienekensens, J. and Zuurbier, P. (2008) Quality and Safety Standards in the Food Industry, Developments and Hallenges. International Journal of Production Economics, 113, 107-122.

[9] Muzzolini, F. (2005) Production alimentaire et environnement. France Agricole RIA Edition.

[10] Gollin, D., Morris, M. and Byerlee, D. (2005) Technology Adoption in Intensive Post Green Revolution Systems. American Journal of Agricultural Economics, 87, 1310-1316.

[11] Tilman, D., Cassman, K.G., Matson, P.A., Naylor, R. and Polasky, S. (2002) Agricultural Sustainability and Intensive Production Practices. Nature, 418, 671-677. http://dx.doi.org/10.1038/nature01014

[12] Vereijken, P. (1992) A Methodic Way to More Sustainable Farming Systems. Netherland Journal of Agricultural Science, 40, 209-224.

[13] Serra, J.A., Domenech, E., Escirche, I. and Marterell, S. (1999) Risk Assessement and Critical Control Points from the Production. International Journal of Food Biology, 46, 9-26.

[14] Buchanan, R.L. and Whiting, R.C. (1998) Risk Assessment: A Means for Linking HACCP Plans and Public Health. Food Protection, 61, 1531-1534.

[15] Bertolini, M., Rizzi, A. and Bevilacqua, M. (2007) An Alternative Approach to HACCP System Implementation. Journal of Food Engineering, 79, 1322-1328. http://dx.doi.org/10.1016/j.jfoodeng.2006.04.038

[16] Fairman, R. and Yapp, C. (2004) Compliance with Food Safety Legislation in Small and Micro Business: Enforcement as an External Motivation. Journal of Environmental Health Research, 3, 40.

[17] Walker, E., Pritchard, C. and Forsythe, S. (2003) Hasard Analysis Critical Control Point and Prerequisite Implementation in Small and Medium Size Food Businesses. Food Control, 14, 169-174.

[18] Sebto, M. (2004) Risques, sécurité sanitaire et processus de decision. Elsevier, Paris.

[19] Durdan, C. (2008) Towards a Socially Responsible Management Control System. Accounting Auditing Accountability Journal, 671-694.

[20] Garcia, M. (2007) Fearne, Co-Regulation as a Possible Model for Food Safety Governance: Opportunitiesfor PublicPrivate Partnerships. Food Policy, 32, 299-314. http://dx.doi.org/10.1016/j.foodpol.2006.07.005

[21] Zwollm, N. and Hirschauer, S. (2006) Reduction of Behaviourral Food Risks: An Analysis of Economic Incentives and Social Context Factors in the German Poultry Chain. Proceeding of the 99th EAAE, Seminar Trust and Risk in Business Networks, Bonn, February 2006.

[22] Scopioni, A., Arena, F., Villa, M. and Saccarola, G. (2001) Integration of Management Systems. Environmental Management and Health. http://dx.doi.org/10.1108/09566160110389906

[23] Guthirie, J., Cuganesan, S. and Ward, L. (2008) Industry Specific Social and Environmental Reporting. The Australian Food Beverage Industry, Accounting Forum. http://dx.doi.org/10.1108/09566160110389906

[24] Unnevehr, L.J. and Jensen, H.H. (1999) The Economic Implications of Using HACCP as a Food Safety Regulatory Standard. Food Policy. http://dx.doi.org/10.1016/S0306-9192(99)00074-3

[25] Adams, C.A. and Frost, G.R. (2008) Integrating Sustainability Reporting into Management Practices. Accounting Forum. 